\title{
A Framework of Global Competence for Engineers: The Need for a Sustainable World
}

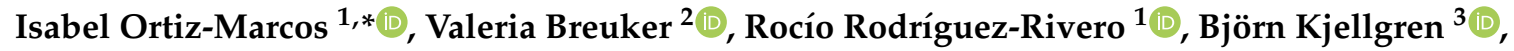 \\ Frédéric Dorel ${ }^{4}$, Marco Toffolon ${ }^{5}{ }^{\circ}$, Diego Uribe ${ }^{1}$ and Virna Eccli ${ }^{5}$ \\ 1 Department of Organization, Business Administration and Statistics, Universidad Politécnica de Madrid, \\ 28006 Madrid, Spain; rocio.rodriguez@upm.es (R.R.-R.); diego.uribe@upm.es (D.U.) \\ 2 Dipartimento di Ingegneria Industriale, Universitá di Trento, 38122 Trento, Italy; valeria.breuker@unitn.it \\ 3 KTH Royal Institute of Technology; 11428 Stockholm, Sweden; bjoern@kth.se \\ 4 École Centrale de Nantes, 44300 Nantes, France; Frederic.Dorel@EC-Nantes.fr \\ 5 Dipartimento di Ingegneria Civile Ambientale e Meccanica, Universitá di Trento, 38123 Trento, Italy; \\ marco.toffolon@unitn.it (M.T.); virna.eccli@unitn.it (V.E.) \\ * Correspondence: isabel.ortiz@upm.es
}

Received: 17 October 2020; Accepted: 14 November 2020; Published: 17 November 2020

\begin{abstract}
This paper presents the results of the first part of the Tools for Enhancing and Assessing the Value of International Experience for Engineers (TA VIE) project, launched in 2018, and outlines a contemporary understanding of global competence for engineers, as understood by European engineering companies. Striving to make engineering education more comprehensively aligned to the United Nation's Sustainable Development Goals (SDGs), and thereby meeting demands from industry and society, the notion of "global competence" has attracted more and more attention from engineering schools. While there is no universally agreed on definition of global competence, the OECD (Organization for Economic Co-operation and Development) definition, which explicitly combines global awareness and intercultural communication competence with sustainability efforts, seems potentially well positioned to inform higher education institutions' (HEI) global competence education. This is perhaps especially so when it comes to international student mobility, an area which is regularly seen as an important means to enhance global competence while all too often being assessed not in terms of qualitative student development, but in terms of structural indicators. However, in order to assess and improve curricula and mobility programs, the desired learning outcomes must first be specified. Based on research in five European countries (Spain, Italy, Sweden, France and Hungary), this paper details the understanding, requirements and perceived skill gaps of companies hiring engineering graduates, a first step towards improved and assessable global competence education for engineering students.
\end{abstract}

Keywords: global competence; internationalization; engineering profession; qualitative research; European comparison

\section{Introduction}

The global world requires an essential emphasis on sustainability in productivity and industrialization processes, all the more with current environmental issues-water supply, deforestation, climate changeas well as sanitary issues like COVID-19, which permeate throughout and threaten all global activity. For these reasons it is absolutely necessary to strengthen global competence for engineers of the future. Over the last three decades, globalization processes have modified the demand for new professional competencies. Engineers are now required to invest in those new competencies to be competitive in the labor market. The traditional concept of modernity, or progress toward more democratic access 
to industrial technology, has now given way to a humbler postmodern situation in the face of the dangers of uncontrolled technology. Preparing engineers no longer means training them in only the Western way, but also in a diversified and multicultural way. This is where both the EU and Tools for Enhancing and Assessing the Value of International Experience for Engineers (TA VIE) have a part to play. Europe is an area where democracy, gender balance, environment and religious tolerance have been gradually taken into consideration, where engineers are trained as citizens of a diverse and complex world, where things happen thanks to negotiating different interconnecting and distant cultures. This is what TA VIE is meant to assess among engineers.

Education systems play a role in forecasting the development of competencies due to their responsibility in preparing students for the labor market. Considering globalization processes, the subject of competency seems to have undergone a transformation. The competencies required for engineers in the international labor market are changing in parallel with the market [1,2]. Engineers are required to have strong technical skills and strong intrapersonal, social, intercultural, and sustainability competencies. Several projects (e.g., Global People, Measuring and Comparing Achievements of Learning Outcomes in Higher Education in Europe (CALOHEE), Time to Assess Learning Outcomes in E-Learning (TALOE), Program for International Student Assessment (PISA)) have investigated the intercultural or global competencies that are more useful to engineers in this perspective. However, there is less work on combining them with the role of international mobility specific to engineering students from a comparative perspective.

Beyond the unification of criteria, institutions must select the strategies and competencies in their programs and courses that best suit their circumstances and objectives. However, this is not to focus only on the composition of the list of competencies, but rather on how they are effectively reflected in the curriculum and respond to the current reality demanded by society, the labor market, the world economy, and the environment [3-5]. Several authors have advocated for increasing the number of engineering students participating in a wider array of global and sustainable learning experiences, both on campus and abroad [6,7], and some initiatives have been launched [8].

More research is needed to identify, aggregate, and validate a comprehensive set of global competencies. In recent years, a number of international projects and initiatives were launched to define academia's role in the development of global competencies. The Bologna Process aimed at creating a European higher education area and led to a new step consisting of total reorganization of the higher engineering education system in Europe and also introduced new ideas about recognizing competencies.

Looking at the consequences of globalization for engineering education, it is time to define some measures for an intelligent adaptation of the engineering curriculum and pedagogy for the new context. For instance, the United Nations General Assembly declared 2005-2014 as the decade of education for sustainable development, which emphasizes the role of education in achieving sustainable development, and assigned the UN Educational, Scientific, and Cultural Organization (UNESCO) to lead its promotion and implementation [9]. These initiatives have helped build a consensus, which is that universities must play a leading role in the transition toward new paths of development $[10,11]$.

This is reflected in the final report of this proposal [12], acknowledging that it is not enough to scale and replicate good teaching practices that have been identified. It is also necessary to have strategic and systemic curricular change involving a whole institutional approach that affects degree and graduate mobility programs, teaching methodologies, research frameworks, and governance, among others. This means that there must be an integrative process that involves all stakeholders and uses sustainable development as an opportunity to transform higher education itself [3,13-15].

These kinds of initiatives help to build consensus, which is that universities must play a leading role in the transition toward new paths of development [16], while also keeping in mind that embedding sustainability into the curriculum does not mean introducing new content or modules into the structure, which is sometimes already overloaded $[12,17,18]$.

The change must involve revising teaching strategies to enhance the development of a critical and holistic vision, introducing interdisciplinary projects among different areas, and promoting 
problem solving and decision making that incorporate criteria of sustainability and ethical and social responsibility [19-21]. To achieve sustainability, it is necessary to cover competencies with a combination of pedagogical approaches. Furthermore, the accomplishment of learning outcomes defined in curricula of degree, graduate, or international mobility programs must be evaluated and reported in order to establish appropriate measurement criteria expected from engineers within a common framework of competency evaluation that meets current global needs $[16,22,23]$.

This paper presents the results of the first intellectual output of TA VIE, an Erasmus+ program. The main goal is to detect the most relevant global competencies required of engineers within the labor market. This first intellectual output was focused on observing these competencies in five European contexts (Spain, Sweden, France, Hungary and Italy) in order to compare them.

In this project, one main interest is to investigate how international mobility, such as the Erasmus experience, international internships, double degrees, and visiting research periods abroad, could contribute to the development of global competencies for engineers. Another related issue is how to figure out the most relevant global competencies expected of the engineer labor market.

\section{Literature Review}

From a theoretical perspective, global and intercultural competence embodies a range of skills, knowledge, attitudes, and behaviors, some of which are easier to assess than others [24]. The global dimension of engineering practice has long been recognized by many scholars and institutions $[1,25,26]$. However, nowadays, there is still a lack of integration of environmental and ethical issues, which do not usually appear in engineering courses. Therefore, there is no systematic or strategic addition among degree programs, making it difficult to incorporate sustainability competencies into the structure of the educational system for future engineers over the long term [27].

For example, conceptualizations of intercultural communication competencies have seen over five decades of scholarly activity. Comprehensive reviews of compositional models can be found in the existing literature (e.g., [28]). Settled at the second International Conference of Engineering Education for Sustainable Development, in the proceedings of the Barcelona Declaration (2004), the importance of sustainable development in technological training was underlined along with promoting higher education in engineering to integrate the Education for Sustainable Development (ESD) goals [3,29] in such a way that engineers can be empowered to change the way they think, reason, and work toward supporting a sustainable future in a global world $[23,30]$. This international declaration specifies the capacities that are considered necessary for engineers to face the challenges of sustainable development. Thus, the competencies included in the document are consistent with the approaches and characteristics of the competencies that are considered basic for an ESD [31] or global competence framework.

In recent years, the European Agenda has increased its focus on the development of new competencies required in a global labor market. Moreover, the Organization for Economic Co-operation and Development (OECD) implemented the Program for International Student Assessment (PISA) survey in 2018 to investigate the global competencies of 15-year-old students [32]. There is increasing awareness of the relevance of a global view in the development of new competencies. This commitment by institutions is related to the globalization and modernization processes that have modified the labor market and contributed to increasing international mobility opportunities for students and workers, especially after the expansion of tertiary education. Many scholars have proposed definitions of global competence as it applies to practicing engineers and students [33-35].

The development of the TA VIE project presented here stemmed from an international collaboration. The partners agreed on the definition of global competence by the OECD which states that, "global competence is the capacity to examine local, global and intercultural issues, to understand and appreciate the perspectives and worldviews of others, to engage in open, appropriate and effective interactions with people from different cultures, and to act for collective well-being and sustainable development" [2]. In this definition there are several observable dimensions. First of all, an important 
aspect is the focus on multiple dimensions (local, global, and intercultural), followed by the capacity to interact with other individuals from different cultures and act for global well-being.

Developing global competence is particularly important in today's changing world because it forecasts sustainable development. Since the modernization process started-where modernization is understood as the growing global and democratic access to unified industrial techniques-many events modified not only the few Western countries, but also the rest of the planet. It was believed that all countries were changing and becoming modern in a similar way, and many scholars in the 1960s and 1970s started to identify similar patterns of modernization and societal evolution [36-40].

The educational system has become more inclusive, and it is now easier to achieve a higher education [41-43]. The demand and supply sides of the labor market have reacted to educational expansion changing the value of educational degrees. Education has gradually transformed into a positional good in labor markets; thus, from the point of view of the returns, the relative position in educational distribution has become more important than before [44]. As a result, the rise of tertiary education contributed to a change in the demand and supply of competencies required in the labor market. As the world's economy has become more connected, so have the interactions among employees around the world.

Even today it is known that technical unification of the world is far from being achieved, with respect to both positive environmental reasons and negative economic and political reasons. The population of engineers is a particularly emblematic example of an occupational category affected by this process, because of the rapidly changing technology that continually transforms engineering practice. Engineering as a profession should be developed based on global approach. In fact, because technology regularly crosses international boundaries, it has become obvious that technology and international interaction are intrinsically entwined. As universities regularly produce graduates who work abroad or work alongside co-workers from other cultures, the importance of providing a global education is more pressing than ever [45]. Many models for global engineering education have been reported in the literature [33].

Moreover, societies have become multicultural and the need for new tools to communicate effectively across cultures has become fundamental. A global world requires an open view, because multicultural communities are growing. This underlines that various cultures live together in specific contexts and need to find balance. It means that in a global world, citizens need to open their perspectives and experiences to current world changes. The modernization process and the development of industrial technologies have led to innovation and growth of information and communications technology (ICT) tools, which have modified several social, economic, and political aspects in all countries in one common direction $[36,46]$.

The industrial revolutions have shown several differences in the demand and supply of competencies in the labor market, due to the development of new occupations related to increased technology and expanded ICT. In many occupations, the need to be globally oriented has increased; for example, engineers need to have a global understanding of the society in which they work in order to understand all the risks and needs related to their job. The variety of capitalisms literature shows that training in these competencies is organized differently in different countries (e.g., [47-49]). This justifies the comparison of global competency development of engineering students between countries.

\section{Global Context of Engineers}

Research in the late twentieth and early twenty-first century mentioned above should now be enriched by current research that highlights the essential role of intercultural awareness, given the multidisciplinary, diverse and global nature of the engineering profession [50] and several engineering federations and accreditation agencies that have addressed this topic.

The Accreditation Board for Engineering and Technology [51] and the European Network for Accreditation of Engineering Education (ENAEE) [52] both stipulate that engineering graduates should understand, "the wider multidisciplinary context of engineering" [52] and, "the impact of engineering 
solutions in a global ... context" [51]. One of ABET's new criteria, introduced in 2019-2020, is, "an ability to apply engineering design to produce solutions that meet specified needs with consideration of public health, safety, and welfare, as well as global, cultural, social, environmental, and economic factors" [53]. This new criterion clearly implies the need for such knowledge and skills by referencing the multidisciplinary, international, dynamic and global nature of the engineering setting.

ENAEE addresses specifically the education of engineers, affirming that its importance is increasing in the global economy. This Network aims to enhance and promote the quality of the education of engineering graduates. Their goal it to facilitate their professional mobility and to enhance their individual and collective ability to fulfil the needs of economies and of society [52].

Launching global engineering programs has faced several challenges $[6,54,55]$. One challenge is the need to increase the importance of global competence defining attributes and capabilities, since it is of high interest in multiple disciplines and has caused some confusion [56]. Another challenge is to design experiences with high impact in terms of developing global competence, by which students discover the meaning of global competence themselves through their engagements and reflections. Moreover, in response to the need to create tools to assess global competence of engineering students, previous researchers $[57,58]$ developed a suite of instruments to measure such competence.

Eventually, developing global competencies is necessary from the perspective of production systems in a global world. In recent years, there has been a change in several aspects of the organizational processes of productivity and educational systems in most Western countries. Universities are beginning to realize the importance of teaching global competence to their engineering students; however, since the term global competence is not universally defined, they often have trouble focusing students' global education on a particular area. The awareness of educational institutions that they have the responsibility to train global engineers is growing. A clear example is the European Universities Initiative, consisting of networks of universities promoted by the European Union to bring together a new generation of Europeans able to work across borders to deal with societal and global challenges such as sustainable development [59]. Another example is programs of skills development that many international universities offer their students, encouraging specific training activities that could foster a global perspective, such as the development of intercultural competence, which is a crucial global competence recognized by the OECD framework. This competence should be developed in a holistic framework that includes cognitive, affective, and behavioral domains [24,60]. That means that students should invest in international opportunities to forecast global competence training.

An interesting point on which educators and experts have focused on in recent years is sustainability competency. Wiek et al. [61] argued the emergence of, "a comprehensive framework of five key competencies emphasized by sustainability experts in academic programs in eight universities," categorized as systems, anticipatory, normative, strategic and interpersonal. Based on their definitions, those competencies have much in common with global competencies. An example is interpersonal competence, which is defined as the, "ability to understand collaborative and participatory sustainability research and problem-solving" [62]. Several sustainability competencies are also defined as global competencies; for example, the authors of [62] argue that students in their sample were required to be prepared for how to interact with local communities.

Education pathways are increasingly looking to promote effective sustainability learning regarding the role of competence-based learning for sustainability, promoting the acquisition of sustainability competencies by students [62]. Yet there remains a lack of quality tools for assessing global competence among engineers and other technical professionals, including their behavioral tendencies in global work situations [54,63,64]. In the engineering field, previous researchers published studies to assess global competence [65] and the Miville-Guzman Universality-Diversity Scale [66-68]. Atman et al. [69] employed a playground design scenario to compare student and expert design behaviors; Downey et al.'s [35] pre-/post-course study design utilized self-reported items, an open-ended scenario question and content knowledge questions (multiple-choice format); and Kilgore et al. [70] used scenario-based assessments in engineering education. 
In a global world, awareness of the need to support sustainable development goals is already required. On both the micro and macro level, decisional organizational processes and project management actions have to consider the global process of skills development.

\section{The TAVIE Project}

The TA VIE project stems from a collaboration of five European Higher Education Institutions (HEIs): Universidad Politécnica de Madrid (UPM) in Spain, KTH Royal Institute of Technology (KTH) in Sweden, École Centrale de Nantes (ECN) in France, Budapesti Muszaki es Gazdasagtudomanyi Egyetem (BME) in Hungary, and Università degli Studi di Trento (UniTrento) in Italy. The chosen countries allow a comparative perspective of different European countries with different educational systems and labor market conditions.

The European Commission invested fundamental resources in the form of, for example, public policy initiatives focusing on the New Skills Agenda. Nowadays, the educational expansion process contributes to the improvement of the quality of educational pathways and reaches many more individuals from various social and economic backgrounds, expanding their opportunities. One of the consequences is that today technical skills alone are not sufficient anymore, and the labor market has enlarged the list of competencies required. Another sort of competence is required in a growing number of occupations, which is the ability to communicate across disciplines, systems, and cultures, as well as self-knowledge. The TA VIE project aims to identify those competencies currently essential to working in multidisciplinary and international contexts and to measure them. The project is an example of the academic effort to contribute to the development of global competencies among students and young professionals. The underlying assumption is that several skills and attitudes can change and improve after international mobility.

The general objective of TA VIE is to develop internationalization strategies and tools for enhancing and assessing global competencies for engineering students and alumni, promote embedded mobility schemes and enforce their quality, and strengthen employability through cooperation across national and organizational borders.

\section{Materials and Methods}

The main goal of the project is to understand the main competencies, skills and behaviors of a global engineer from the perspective of companies. Within this goal lies an interest in observing whether there could be a mismatch between graduate and occupational competencies.

After the preliminary phase, the teams conducted 37 semi-structured interviews to distinguish the most relevant global competencies. Each interview lasted approximately one hour and consisted of two differentiate parts. The first part implied to respond to the following three questions: (i) which competencies do engineers you recruit in your company need?; (ii) which competencies do engineers not have today?; (iii) does international mobility add value to engineers? The second part was to select from the given list of OECD competencies, which ones were the most important for each organization when recruiting engineers. In this part, they could also add some competencies if they did not find them on the list. The interviews were conducted with HR specialists of engineering companies located in participating countries. Researchers interviewed diverse companies of varying dimensions (number of employers, number of engineers hired, number of international businesses and production, geographic location), based on the advantage of being able to observe more variability across companies and determined whether the framework of global competencies they recognize as important were similar or not.

At least five interviews were conducted in each country, and in countries that had the opportunity to deepen the framework, more interviews were conducted. The questions were meant to detect which competencies are the most relevant and which are missing in most candidates. The teams referred to the four OECD dimensions [32]. More precisely, a figure representing the OECD global competencies is proposed (Figure 1), which distinguishes the four dimensions. 


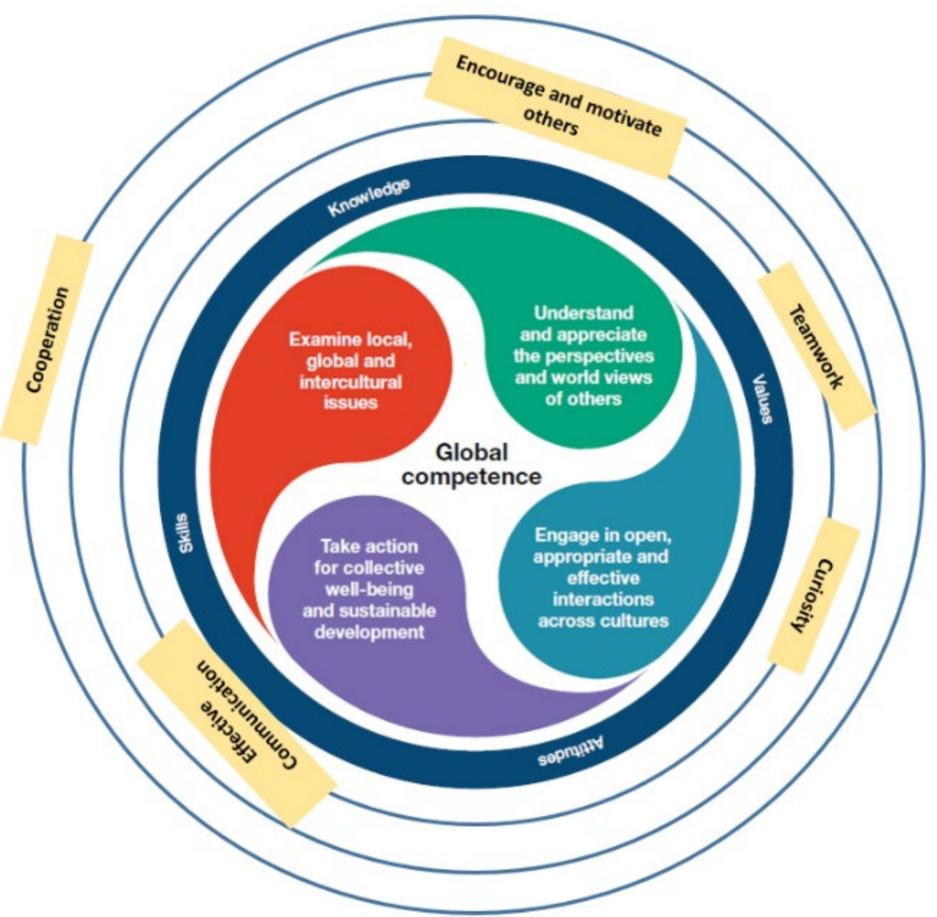

Figure 1. Global competency dimensions defined by Organization for Economic Cooperation and Development (OECD) [32].

The interviewee could make a selection from a list of 35 competencies, that were selected based on a literature review and previous projects about global competencies of engineers, shown in Table 1. The HR specialists had the chance to add other competencies relevant to their personal experience or referring to the companies where they worked. In several cases, other competences were added.

Table 1. List of global competencies, attitudes, and personal traits.

\begin{tabular}{ccc}
\hline Competency & Attitude & Personal Trait \\
\hline Communication & Openness & Acceptance of differences \\
Communication in a foreign language & Flexibility & Coping \\
Holistic system thinking & Adaptability & Resilience \\
Negotiation & Curiosity & Initiative \\
Conflict management & Assertiveness & Oriented to face challenges \\
Cooperation & Self-awareness & Oriented to face challenges \\
Problem solving & Empathy & Creativity \\
Encourage and motivate others & International orientation & Grit/perseverance \\
Teamwork & Sociability & \\
Understand the connectedness of the & & \\
world & & \\
Decision making & & \\
\hline
\end{tabular}

Subsequently, the chosen global competencies were validated through focus groups and/or multiplier events in each country. In these contexts, the team's goal was to validate the findings of the interviews and answer three questions: (1) What are the most important competencies for engineering students to succeed in the workplace? How do you define these skills? (2) Does international mobility help develop these competences? How? (3) Which competencies are missing in our analysis?

During the focus groups, researchers discussed each question separately, with $20 \mathrm{~min}$ for each question and tried to involve all participants and give them a similar amount of time to explain their experience. The focus group experience was recorded to facilitate transcription of the discussion. The focus groups were useful to deepen the results of the interviews. With awareness of the small 
sample size, the empirical evidence was checked, comparing it among individuals from different backgrounds to enrich the empirical materials. In each country there was a multiplier event with the principal aim of presenting and discussing the empirical results with new companies. The data collection had an explorative aim, because a further step of the TA VIE project will be to conduct interviews with students focusing more on the role of international mobility.

Finally, a design thinking session was conducted with the participation of all partners to create a framework of competencies for engineering considering previous work in all countries (see Figure 2, research logic).

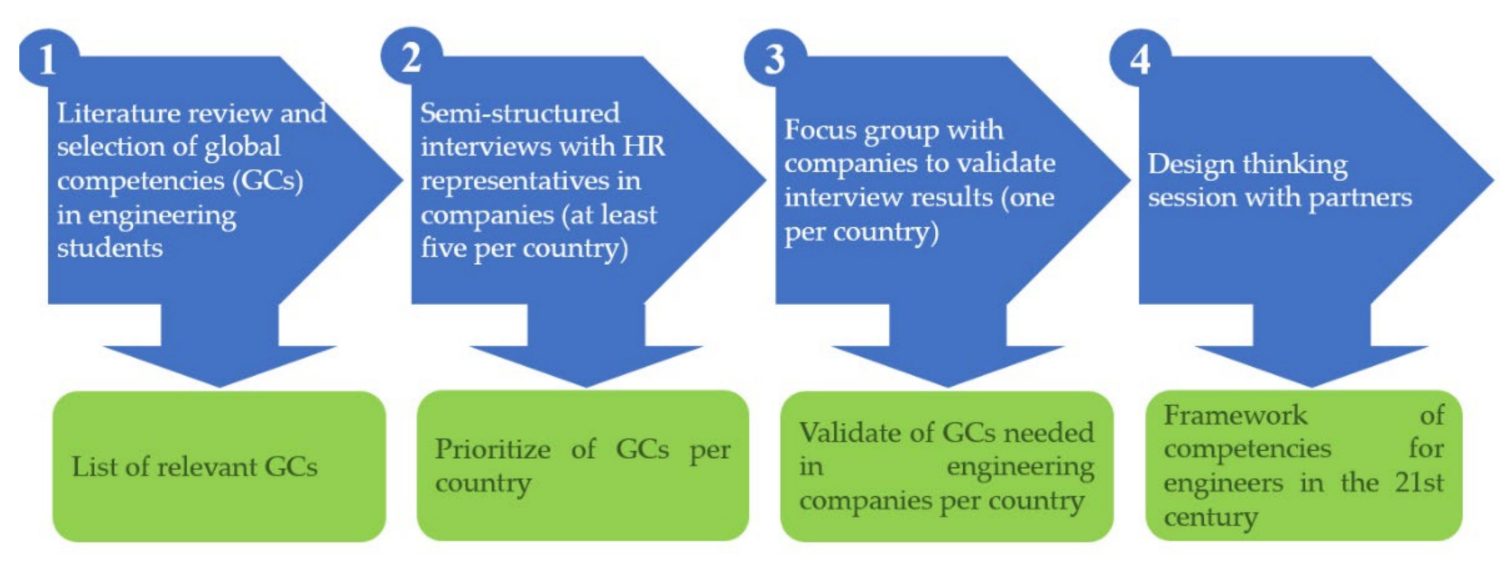

Figure 2. Research logic.

\section{Results}

\subsection{Results from Trento}

\subsubsection{Outcomes from Interviews and Focus Group}

This section presents the empirical results of the analysis conducted in Trento. The UniTrento team selected 10 companies in the area characterized by different dimensions, geographical features and levels of internationalization. All companies agreed to choose 12 competencies identified as more relevant for graduates to enhance their professional career. For the HR specialists interviewed, flexibility was identified as the most relevant global competence. The second most relevant global competency identified was problem solving. For this competency, the HR specialists underlined various features required in different industrial contexts. The most relevant global competencies identified in Trento are presented in Table 2.

Communication in a foreign language and communication are considered tools to interact with and understand others. They are even more relevant when engineers need to learn how to deal with various dimensions. Teamwork, cooperation and conflict management were also seen as fundamental. These competencies are related to interactions with others, using one's own resources, and going beyond the background, role, or perspective of others. They involve respect for others and a willingness to be open to the unknown. Being performance and challenge oriented is also seen as relevant. From the empirical results, it appears that employees with these three competencies have a strong motivation to produce good results, are hard workers, and are curious and eager to learn. The final relevant competencies are adaptability and empathy. Engineers with both of these competencies pay particular attention to their colleagues, are sensitive to the contextual conditions, and are able to change their behavior and communication so as to adapt to the situation. 
Table 2. The most relevant global competencies and missed competencies identified by five countries.

\begin{tabular}{|c|c|c|c|c|c|}
\hline Countries & Trento (Italy) & Madrid (Spain) & $\begin{array}{l}\text { Stockholm } \\
\text { (Sweden) }\end{array}$ & $\begin{array}{l}\text { Nantes } \\
\text { (France) }\end{array}$ & $\begin{array}{l}\text { Budapest } \\
\text { (Hungry) }\end{array}$ \\
\hline \multicolumn{6}{|c|}{ Global Competencies } \\
\hline \multirow{5}{*}{ Competencies } & $\begin{array}{l}\text { Communication in } \\
\text { a foreign language }\end{array}$ & Communication & Communication & $\begin{array}{l}\text { Decision } \\
\text { making }\end{array}$ & $\begin{array}{l}\text { Communication in } \\
\text { a foreign language, } \\
\text { mainly English }\end{array}$ \\
\hline & Communication & Negotiation & & $\begin{array}{c}\text { Ability to } \\
\text { support and } \\
\text { motivate others }\end{array}$ & Cooperation \\
\hline & Cooperation & Cooperation & Cooperation & & \\
\hline & Problem solving & $\begin{array}{l}\text { Encourage and } \\
\text { motivate others }\end{array}$ & Problem solving & & Problem solving \\
\hline & Teamwork & Teamwork & Teamwork & & Teamwork \\
\hline \multirow{5}{*}{ Attitudes } & Flexibility & Flexibility & Relation building & Flexibility & \\
\hline & Adaptability & Adaptability & Adaptability & Adaptability & \\
\hline & Empathy & Empathy & Empathy & & \\
\hline & $\begin{array}{l}\text { Conflict } \\
\text { management }\end{array}$ & Assertiveness & Openness & & \\
\hline & & Curiosity & Curiosity & & \\
\hline \multirow{8}{*}{ Personal traits } & Initiative & Taking initiative & $\begin{array}{l}\text { Performance } \\
\text { oriented }\end{array}$ & & Taking initiative \\
\hline & $\begin{array}{c}\text { Performance } \\
\text { oriented }\end{array}$ & $\begin{array}{l}\text { Acceptance of } \\
\text { differences }\end{array}$ & $\begin{array}{l}\text { Acceptance of } \\
\text { differences }\end{array}$ & & \\
\hline & $\begin{array}{l}\text { Oriented to face } \\
\text { challenges }\end{array}$ & Openness & $\begin{array}{l}\text { Oriented to face } \\
\text { challenges }\end{array}$ & & $\begin{array}{l}\text { Oriented to face } \\
\text { challenges }\end{array}$ \\
\hline & & Convincing & Service minded & Autonomy & \\
\hline & & $\begin{array}{l}\text { Oriented to face } \\
\text { challenges }\end{array}$ & Sociability & Sociability & \\
\hline & & Resilience & & Resilience & \\
\hline & & Perseverance & & & \\
\hline & & $\begin{array}{l}\text { Relation building } \\
\text { Leadership }\end{array}$ & & & \\
\hline \multirow{9}{*}{$\begin{array}{c}\text { Missed } \\
\text { competencies }\end{array}$} & $\begin{array}{l}\text { Ability to take } \\
\text { decisions }\end{array}$ & $\begin{array}{l}\text { Emotional } \\
\text { intelligence }\end{array}$ & Communication & Empathy & $\begin{array}{l}\text { Understand the } \\
\text { complexity of } \\
\text { company } \\
\text { objectives }\end{array}$ \\
\hline & Flexibility/adaptability & Active listening & Sociability & $\begin{array}{l}\text { Emotional } \\
\text { intelligence }\end{array}$ & $\begin{array}{l}\text { Understand the } \\
\text { main line of work } \\
\text { processes }\end{array}$ \\
\hline & Communication & Detail oriented & Presenting & $\begin{array}{l}\text { Interpreting } \\
\text { financial } \\
\text { statements }\end{array}$ & Holistic thinking \\
\hline & Sociability & $\begin{array}{l}\text { Assuredness/speaking } \\
\text { impact }\end{array}$ & Selling & $\begin{array}{l}\text { Managing } \\
\text { budgets }\end{array}$ & Communication \\
\hline & $\begin{array}{l}\text { Awareness of one's } \\
\text { own potential, } \\
\text { competencies, and } \\
\text { skills (self-efficacy) }\end{array}$ & Commitment & & Cooperation & Flexibility \\
\hline & & $\begin{array}{l}\text { Ambition inside } \\
\text { the company }\end{array}$ & & Interaction & $\begin{array}{l}\text { Open to manage } \\
\text { changes }\end{array}$ \\
\hline & & Long-term vision & & Flexibility & \\
\hline & & Patience & & Leadership & \\
\hline & & $\begin{array}{c}\text { Social and } \\
\text { sustainability focus }\end{array}$ & & & \\
\hline
\end{tabular}

To discuss and deepen the results of the interviews, a focus group was organized, to which the interviewed companies were invited (four participated) together with a member of the federation of Italian employers (Confindustria), a member of Hub Innovation Trento (HIT), two double-degree students, a representative of the international office of the University of Ferrara and four academics from the University of Trento involved in international relations.

The added value was to invite not only some of the companies that participated in the interviews, but also several other actors to enrich the discussion. After the discussion, it was possible to confirm most of the competencies that were selected in the interviews. This is an encouraging aspect, 
especially because of the small sample size. Only communication and communication in a foreign language were excluded from the selected competencies during the focus group. The paradoxical reason is that these are considered crucial from the beginning of the recruitment process. The other 10 global competencies chosen during the interviews were considered the most relevant to enhance employability for engineers.

\subsubsection{Recent Graduates' Global Competencies: What Is Missing?}

Another important aspect is the competencies lacking in most of the applicants, according to the companies. Some graduates often have very strong technical skills, but they lack other competencies considered equally important. While some graduates probably developed some of these skills independently, they are not sufficiently strong in others. In particular, most of the recently hired engineers lacked the ability to make decisions.

Many companies selected flexibility as the most required competency, and this is also one of the most difficult to find in young engineers. Flexibility and adaptability are two global competencies that are often developed during one's career, but very often these are personal features.

Another noted limitation of engineering graduates is the ability to properly explain and effectively understand most of the points. This involves both interpersonal communication or sociability, and more technical explanations of what they have done on the job. Many of the employees spend little time interacting with peers and colleagues or supervisors, and most of them send emails related to job tasks.

Another important missing aspect which seems to be related to the ability to properly explain and effectively understand points, is awareness of one's own potential, competencies and skills (self-efficacy). Most graduates or young professionals are not conscious of what they are good at or their personal and professional characteristics. This aspect has an important impact on decisions regarding specific occupational opportunities and can influence individuals during job interviews because they do not properly explain their strengths.

The missing global competencies for engineering graduates of Trento appear in Table 2.

The interesting point is that most of these were among those considered more relevant. This suggests a trade-off. On the one hand, companies in the Trento area are looking for engineers who are more flexible and adaptable and can communicate properly, but on the other hand, most of the applicants are characterized by a lack of these competencies.

\subsubsection{Global Competence and International Mobility}

This section disentangles one of the main concerns of the TA VIE project, which is the role of international mobility in the development of global competencies. Indeed, this point seems to be one of the strengths of the project.

To confirm the relevance of flexibility in the actual labor market, the interviewees explained that most of the employees who experienced international mobility during their educational career were more flexible in their job. In particular, they seemed to be more open-minded and interested in what was different in order to adapt easily to the context. Moreover, the HR specialists noted that individuals with some international experience (not only in their studies but also in volunteering activities or international training) developed a stronger sense of adaptability. This competency characterizes individuals who study the context and adjust to it.

A strictly related global competency that is essential to companies in this area is the ability to solve problems. This ability is linked to two other competencies, being performance oriented and facing challenges. These competencies are fundamental in a global world because it is crucial to be able to face difficulties, get out of one's comfort zone, and build ties with people from other countries and cultures. Indeed, the last essential global competency in this context is sociability, which can increase by having experience with international mobility and being encouraged to meet new people, particularly natives, and develop relationships in new contexts. Introducing new elements to their personality, 
international mobility contributes to students' personal growths because they are compelled to step out of their comfort zone and learn how to approach new contexts.

\subsection{Results from Madrid}

\subsubsection{Outcomes from Interviews and Focus Group}

This section presents the empirical results of the analysis conducted in Madrid. The UPM team collected data from six interviews with participants from two Spanish companies and four international companies. All of them recruit engineers of different fields. The HR specialists highlighted that companies consider the competency communicating in a foreign language a must, and they do not recruit engineers who have not achieved the required foreign language level.

To analyze the results, only the competencies that were highlighted at least by four companies were considered. These are presented in Table 2.

Once the interviews were finished, results were contrasted in a focus group with 18 participants from six companies and the UPM. The focus group was led by working in three different teams. Participants were asked to organize competencies considering how important they were to their company and how satisfied they were with engineers who were recruited upon finishing their studies. This analysis was done to differentiate between competencies that companies required, versus the ones engineers already have and those they miss.

From the focus group it emerged that some competencies are very important but are not always demonstrated in the company. Indeed, some competencies are very important and frequently demonstrated such as resilience, active listening, self-awareness, humility, perseverance, analytical thinking and attention to detail, impact and influence. Some competencies did not emerge during the interviews, like humility and impact and influence. During the discussion, participants suggested several competencies that are very important but rarely demonstrated such as long-term vision, transcultural empathy, promotion of change, open mindedness, creativity, negotiation and communication, ethical orientation, teamwork, networking and curiosity.

\subsubsection{Recent Graduates' Global Competencies: What Is Missing?}

During the interviews, the focus was also on the competencies that were missing in engineering students when they entered the labor market. Apart from the ones that have already been highlighted, companies expressed a need for other competencies that were not considered in the questionnaire. They appear in Table 2.

HR specialists argued that young professionals lack interpersonal and soft skills and are more oriented toward technical competencies. Companies highlighted that global competencies at least had the same relevance as technical skills, but HEIs still invest poorly in developing these sorts of competencies.

\subsubsection{Global Competencies and International Mobility}

After completing the analysis of companies (through the interviews and focus group), it is possible to present the competencies that companies require from engineers to work in an international context today. They all highlight the importance of communication skills, with a special emphasis on transcultural empathy, openness/ open-mindedness, assertiveness, and active listening. Competencies linked with adaptability/change acceptance were also highlighted, with an emphasis on resilience and perseverance.

In the global environment, teamwork was also considered by companies to be a priority for engineers. Teamwork, curiosity and analytical thinking and attention to detail were also considered important. Finally, leadership skills were highlighted. Competence in encouraging and motivating others, negotiation and long-term vision are needed. 
This analysis confirms the need to strengthen soft skills while companies consider that engineers from UPM have a high level of required hard competencies in the labor market.

\subsection{Results from Stockholm}

\subsubsection{Outcomes from Interviews}

Royal Institute of Technology, KTH's TA VIE team, collected data from seven HR specialists in Stockholm, five of whom were from organizations of different sizes, professional fields, and levels of internationalization, and two from recruitment agencies for engineers. While none of the suggested items were deemed completely unimportant, some strongly varied in their valuation by respondents. The skills most valued by the respondents in Stockholm: are presented in Table 2.

When taking a closer look at these highly ranked items and those additionally brought up by the respondents, it appears that these relate to personal, interactional, and organizational dimensions. Engineers should have certain personal qualities, be able to interact with others and create additional value for their organization. However, it should be noted that the items related to creating value for the organization (e.g., performance oriented, service minded, presentation skills, sales perspective) obviously play a role for recruiters and for-profit organizations but should be seen in our context as potential consequences of the global competencies fostered by international mobility. Moreover, while communication and interaction skills were repeatedly ranked highly, the recruiters also pointed out that they first looked at technical know-how before considering those additional skills. This should not be surprising, as their organizations work in highly specialized technical fields and engineers are in high demand in Stockholm and the Swedish labor market in general. One recruiter compared previous experience to working in a country in Eastern Europe, where engineers were more in demand and therefore had less need to show skills other than basic engineering proficiency.

\subsubsection{Recent Graduates' Global Competencies: What is Missing?}

In the Stockholm sample, recruiters especially lamented the lack of communication skills. Similarly, other missing skills were related to presentation and sales, which could also be grouped in the field of communication. As communication was also clearly rated as the most important global competency in the Swedish sample, it appears crucial that universities find ways to enhance this competency in graduates.

The missing competencies are listed in Table 2.

\subsubsection{Global Competencies and International Mobility}

Regarding the importance of international mobility for engineering graduates in the job market, opinions were mixed among the respondents. While one recruiter claimed that their international organization would only hire people with international experience, many others praised international experience for fostering personal self-development and openness. While actively going abroad seemed to not be important for this recruiter, that might be connected to the context of higher education in Sweden. Sweden has many incoming foreign exchange students, which leads to many opportunities for Swedish students to connect with people from different backgrounds and engage in internationalization at home. Most Swedish engineering graduates can also be assumed to have experience in other countries through gap years and/or holiday travels.

\subsection{Results from Nantes}

\subsubsection{Outcomes from Interviews}

This section presents the empirical results of the analysis conducted in Nantes. In the case study, participants were interviewed from 10 companies, all with different dimensions, geographic features and levels of internationalization. Engineers are recruited in several areas nowadays, not only in 
traditional industrial fields, but also in non-industrial fields where they are needed. This variety highlights the necessity for engineers to develop social and global competency in order to contribute in any technical, scientific, or human environment.

The empirical results from the interviews in Nantes show that two major competencies stood out. The human resources specialists agreed that adaptability and the ability to support and motivate others are the most relevant in the French engineering companies of the sample. Moreover, they underlined that a global engineer should have at least 5 of the 35 proposed competencies in the initial lists. Those identified as most important are presented in Table 2.

This gap of perception could be explained by the divergence between types of company, positions of recruited applicants (various levels of seniority of recruited engineers and staff employers) and corporate cultures.

For 6 of the 10 companies, graduation in a foreign country is appreciated but not necessarily looked for. The HR specialists suggested that young engineers should be fluent in public speaking, have experience in teamwork/projects (to enhance cooperation and interaction), and improve partnerships with other universities or social entities. Universities should be able to prepare students for the corporate world.

It is not completely clear whether studying abroad is no longer a plus that occurs at an unavoidable point in the curriculum of an engineer. Indeed, six companies identified it as positive, and the other four as negative. This can be interpreted as meaning that there is no consistency in the relevance of international mobility to the development of competencies. It seems that in general the answer is connected to the sort of company, in particular to its degree of internationality and dimension. Most of the information was collected during the last two job network session held in Italy in Milan in May 2018 and Torino in May 2019 organized by Centrale Nantes, the Groupe des Ecoles Centrale, the T.I.M.E. Network, the PoliMilano and the PoliTorino.

\subsubsection{Recent Graduates' Global Competencies: What Is Missing?}

During the interview some space was given to understand whether there are some competencies that appear to be important in the company's perspective, but that are often missing in the engineers that are hired. According to the 10 companies, several young engineers lack interpersonal and social competencies. The HR specialist underlined the missing social competencies shown in Table 2.

\subsubsection{Global Competencies and International Mobility}

The interviews showed some uncertainty about the relevance of international experience in improving global competencies $(60 \%$ versus $40 \%)$. This suggests that this relationship should be investigated in more depth. Of course, it appears to be a key issue, because going abroad and having new experiences allows us to understand new personality aspects, but it is not clear whether specific global competencies can change after such experiences.

International mobility has always been regarded as essential to the development of social skills, but without any specific evidence. During the interviews, several HR specialists underlined that often candidates and young professionals who had international mobility experience appeared more skilled than their colleagues who had no experience abroad. Indeed, the competencies adaptability and ability to face challenge in an international context, as identified by the Centrale Nantes team, specifically echo those identified by the University of Trento team, i.e., flexibility, problem solving and sociability, which shows that in spite of the diversity of regions, the same priorities emerge in the recruitment of international engineers. 


\subsection{Results from Budapest}

\subsubsection{Outcomes from Interviews and Focus Group}

This section presents the empirical results of the analysis conducted in Budapest. The case study involved four companies characterized by different dimensions, geographic features, and levels of internationalization. The main picture that emerges from this analysis is awareness of the strong limitation of the sample size. In spite of the internal differences among the companies, several common answers were registered.

The most relevant global competencies identified during the interviews emphasized problem solving and holistic thinking, but also underlined communication in a foreign language (English), resilience, change management skills, being oriented to face challenges, communication and good social skills. They also mentioned service mindedness, but one of the companies added that for them it means being customer oriented. Regarding attitudes, they referred to openness, flexibility, adaptability and curiosity. Competencies like independence and service mindedness were also mentioned.

Interviewed companies need engineers who have a high level of problem solving competence and good communication skills (mainly in English). All of those interviewed also added flexibility as another important element, which includes openness and change management skills. Employees can only be flexible if they are ready to make changes during work if needed.

For two of the companies, international mobility and relations are essential, for the others they are becoming more important. The global competencies identified as most relevant are presented in Table 2.In this case, companies highlighted that engineers lack competencies such as complexity of viewpoints and communication (language skills).

During the focus group, researchers had the chance to ask questions of company representatives, students and university professors and discuss the importance of cooperation between industry and academia, while the respondents also gave their views on the competencies that are important for engineers to have. They emphasized nearly the same competencies as in the interviews.

They also stated that there was a lack of some competencies even if they could recruit the best students, such as complex viewpoint, communication (language skills) and rigorousness in a living environment not only theoretically. The conclusion was that industry could teach students to be committed to deadlines, quality, responsibility and real solutions.

\subsubsection{Recent Graduates' Global Competencies: What Is Missing?}

Companies mentioned several global competencies that engineers already possess. However, they also noted that many other competencies would be needed but are still lacking, in many cases unexpectedly. It was interesting that the majority of managers interviewed would highly appreciate candidates who can see the complexity of company objectives and therefore can understand the main line of work processes. Two companies especially stressed that they need people who have holistic thinking, but this skill is often not available. Another striking shortage is communication, in either the mother tongue or a foreign language. The four participants interviewed in Hungary, however, claimed that there is a real lack of fresh graduate engineers. They explained that it is not the most important competency, as it is about the engineering profile. They first need professional engineers who know cutting-edge technologies. However, it was emphasized that possessing good communication skills would be important and advantageous, whereas it is still a missing competency in the country. More research-based firms added that they do not insist on excellent communication skills because engineers are often introverts.

Referring to the most relevant global competencies, it seems a real challenge that companies would need employees who are flexible and open to manage changes. However, what if those people lack coping strategies? On the other hand, what if they are flexible but do not have stamina? This kind of contradiction often appears in everyday life. The competencies identified as missing are listed in Table 2. 
Most of these came from the interviews and focus group. HR specialists added understanding the complexity of company objectives, understanding the main line of work processes and open to manage changes.

\subsubsection{Global Competencies and International Mobility}

This section disentangles one of the main concerns of the TA VIE project, which is the role of international mobility in the development of global competencies. The HR specialists underlined the relevance of international experience to being a global engineer. The biggest company mentioned an extra competency, which is showing good leadership. They explained that it is actually a complex competency that involves applied thinking, being engaged and being able to adapt well to changes.

The smallest company said that, as they realized they needed employees with good communication skills in foreign languages, they let them go abroad for longer periods (3-4 years) to gain this experience. This seems to be a huge risk in terms of the size of the company (16 people), but the manager is convinced that this is an important investment in the future even if it is risky, because this way they can gain more experienced colleagues.

All companies agreed without a doubt that engineering students who have the opportunity and possibility to participate in international mobility during their studies should do so, because through the experience gained, they can develop the most effective global competencies. Being able to work in an international environment can help to position someone in a leading role.

\section{Discussion: Global Empirical Evidence}

This section puts together all of the empirical results from the five countries involved in the TA VIE project, with the aim of developing a common framework of competencies. Comparing the results of the different contexts, it is possible to find some similarities and some differences, probably related to the economic context and the peculiarities of the national labor markets. There are five competencies to be found in all countries: flexibility, adaptability, teamwork, oriented to face challenges, and cooperation. All of the others were found in one or some of the countries.

In the initial stage of the analysis, 35 competencies were selected from the literature review [71] and the analysis of previous projects.

After finalizing the competence framework, the TA VIE team ended up with 37 global competencies for engineering students to be tested on identified in the interviews and focus groups in the five countries. During some interviews some relevant global competencies emerged that were not considered in the beginning of the research design and were added to the list. For each competency, the teams identified a definition based on the existing literature and the empirical results and an item performance indicator for self-assessment. In the following step of the project the teams will measure students' global competencies using these items.

The 37 competencies were organized in three macro clusters (Table 3), which fall into three dimensions: organizational, relational and self-knowledge competencies. TA VIE members conducted a session using design thinking methodology and identified six sublevels: service to organization, cooperation, communication, leadership, self-awareness and proactivity. In each of the six groups, more specific global competencies are linked.

From the first intellectual output of the TA VIE project it can be argued that companies in general give added value to international experience, because it enriches an individual's perspective and personality. International mobility can act as insurance for an employee with stronger global and soft skills. 
Table 3. Clusters and definitions of global competencies.

\begin{tabular}{|c|c|c|c|}
\hline Cluster & Competencies & Definition & $\begin{array}{l}\text { Item Performance Indicator for } \\
\text { Self-Assessment }\end{array}$ \\
\hline \multirow{5}{*}{ 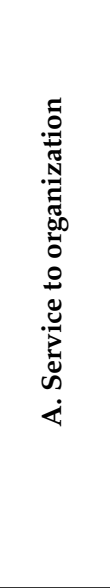 } & Performance oriented & $\begin{array}{l}\text { Strong willingness to succeed and reach aims, } \\
\text { engaging in multiple tasks and working long hours; } \\
\text { strong motivation to use own and new resources to } \\
\text { achieve goals }\end{array}$ & $\begin{array}{l}\text { Demonstrates willingness and motivation by } \\
\text { actively working to achieve goals/results }\end{array}$ \\
\hline & Structured & $\begin{array}{l}\text { Ability to organize and prioritize tasks and } \\
\text { time effectively }\end{array}$ & $\begin{array}{l}\text { Organizes and prioritizes tasks and } \\
\text { time effectively }\end{array}$ \\
\hline & Conscientiousness & $\begin{array}{l}\text { Implies a desire to be effective and efficient at doing } \\
\text { tasks and to take obligations to others seriously }\end{array}$ & $\begin{array}{l}\text { Takes on obligations and works to efficiently } \\
\text { create best and most sustainable results }\end{array}$ \\
\hline & Service-mindedness & $\begin{array}{l}\text { Ability to find easy solutions to questions or } \\
\text { problems; often collaborates with colleagues and is } \\
\text { motivated to reach the aim }\end{array}$ & $\begin{array}{l}\text { Collaborates and interacts with others to achieve } \\
\text { set goals }\end{array}$ \\
\hline & Analytical thinking/attention to detail & $\begin{array}{l}\text { Ability to solve detailed problems effectively; } \\
\text { involves methodical step-by-step approach to } \\
\text { thinking that allows one to break down complex } \\
\text { problems into smaller, manageable components }\end{array}$ & $\begin{array}{l}\text { Follows a step-by-step approach to solve } \\
\text { problems effectively, showing attention to detail }\end{array}$ \\
\hline \multirow{6}{*}{ 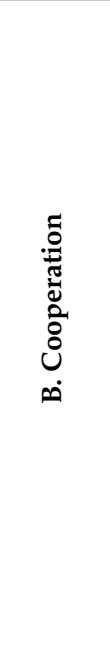 } & Adaptability & $\begin{array}{l}\text { Ability to change habits or actions or approach } \\
\text { habits based on the environment }\end{array}$ & $\begin{array}{l}\text { Demonstrates ability to change in order to adapt } \\
\text { to different environments and cultures }\end{array}$ \\
\hline & Flexibility & Easily changes behavior/judgement & $\begin{array}{l}\text { Changes behaviors/judgments easily when } \\
\text { necessary, open to others' perspectives }\end{array}$ \\
\hline & Collaboration & $\begin{array}{l}\text { Members work together, share tasks in a } \\
\text { coordinated way, avoid conflicts, listen to others' } \\
\text { opinions, and express their own views }\end{array}$ & $\begin{array}{l}\text { Works together, shares tasks, and cooperates } \\
\text { with others in multicultural environments }\end{array}$ \\
\hline & Teamwork & $\begin{array}{l}\text { Ability and willingness to share tasks and } \\
\text { responsibilities and collaborate with coworkers; } \\
\text { listens to and evaluates other perspectives }\end{array}$ & $\begin{array}{c}\text { Shares responsibilities, tasks, and commitment } \\
\text { with mates on a diverse team to achieve } \\
\text { common goals }\end{array}$ \\
\hline & Sociability & $\begin{array}{c}\text { Willingness to support co-workers, develop team } \\
\text { building activities, participate actively in team } \\
\text { meetings, share information, knowledge, } \\
\text { and experiences }\end{array}$ & $\begin{array}{c}\text { Creates new relationships, actively participates } \\
\text { in team meetings and activities in a } \\
\text { multicultural environment }\end{array}$ \\
\hline & Relation building & $\begin{array}{l}\text { Capacity to invest time in establishing good } \\
\text { working relationships }\end{array}$ & $\begin{array}{l}\text { Creates environments of trust, respect, and } \\
\text { support for others, invests time to establish good } \\
\text { working relationships that respect diversity }\end{array}$ \\
\hline
\end{tabular}


Table 3. Cont.

\begin{tabular}{|c|c|c|c|}
\hline Cluster & Competencies & Definition & $\begin{array}{l}\text { Item Performance Indicator for } \\
\text { Self-Assessment }\end{array}$ \\
\hline \multirow{7}{*}{ 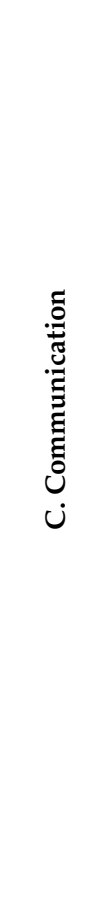 } & Communication in a foreign language & $\begin{array}{l}\text { Capacity to express own thoughts and understand } \\
\text { others, and interact with others in one or more } \\
\text { foreign languages }\end{array}$ & Expresses oneself clearly in a foreign language \\
\hline & Presentation skills & $\begin{array}{l}\text { Ability to explain and conceptualize a topic clearly, } \\
\text { making sure the audience understands the message }\end{array}$ & $\begin{array}{l}\text { Presents ideas clearly, adapts to the audience, } \\
\text { and makes sure the message has been } \\
\text { understood }\end{array}$ \\
\hline & Active listening & $\begin{array}{l}\text { Listens attentively, showing signals that listening is } \\
\text { taking place; regularly checks and clarifies } \\
\text { meanings of important words and phrases to ensure } \\
\text { that all participants attach the same meanings, even } \\
\text { when they are well known; notices potential } \\
\text { misunderstandings and seeks clarification or } \\
\text { negotiates until common understanding is reached }\end{array}$ & $\begin{array}{l}\text { Listens actively and asks for clarification } \\
\text { when needed }\end{array}$ \\
\hline & Humility & $\begin{array}{l}\text { Holds in mind one's limitations and does not } \\
\text { believe one is better than others }\end{array}$ & $\begin{array}{c}\text { Maintains others' and own opinions on the same } \\
\text { level, appreciating perspectives and world } \\
\text { views of others }\end{array}$ \\
\hline & Empathy & $\begin{array}{l}\text { Understands a set of behaviors and social norms } \\
\text { more accepted in a specific environment and adapts } \\
\text { to the context }\end{array}$ & $\begin{array}{c}\text { Is aware of others' feelings, emotions, and social } \\
\text { norms, understands behaviors, and is } \\
\text { supportive when needed }\end{array}$ \\
\hline & Assertiveness & $\begin{array}{l}\text { Expresses opinions calmly with conviction, even if } \\
\text { different from others'; is open to dialogue }\end{array}$ & $\begin{array}{l}\text { Expresses opinions calmly, with confidence and } \\
\text { respect for diversity }\end{array}$ \\
\hline & Convincing & $\begin{array}{l}\text { Sharp, eloquent, and to the point; confident and } \\
\text { assertive; concise and focused when discussing } \\
\text { beliefs and arguments }\end{array}$ & $\begin{array}{c}\text { Convinces others of one's ideas with concise and } \\
\text { eloquent arguments }\end{array}$ \\
\hline
\end{tabular}


Table 3. Cont

\begin{tabular}{|c|c|c|c|}
\hline Cluster & Competencies & Definition & $\begin{array}{l}\text { Item Performance Indicator for } \\
\text { Self-Assessment }\end{array}$ \\
\hline \multirow{8}{*}{ 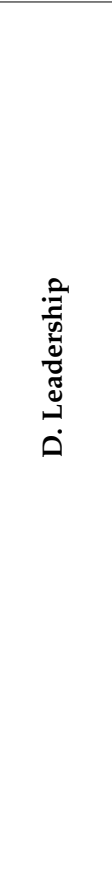 } & Negotiation & $\begin{array}{l}\text { Ability to encourage teamwork; forges team identity } \\
\text { and can mediate in most situations of conflict }\end{array}$ & $\begin{array}{l}\text { Achieves agreement and commitment taking } \\
\text { into account interests of different stakeholders }\end{array}$ \\
\hline & Decision making & $\begin{array}{l}\text { Evaluates various possibilities carefully and able to } \\
\text { indicate the best decision }\end{array}$ & $\begin{array}{l}\text { Makes informed decisions based on relevant } \\
\text { information at the appropriate time }\end{array}$ \\
\hline & Problem solving & $\begin{array}{l}\text { Able to analyze a situation, recognize an issue, and } \\
\text { analyze features of a problem; evaluates how to } \\
\text { intervene and find resources for the most } \\
\text { reasonable solution }\end{array}$ & $\begin{array}{c}\text { Identifies, faces, and effectively solves problems } \\
\text { that arise }\end{array}$ \\
\hline & Encourage and motivate others & $\begin{array}{l}\text { Shares knowledge and discusses visions with } \\
\text { possible partners }\end{array}$ & $\begin{array}{l}\text { Encourages, empowers, and motivates others to } \\
\text { achieve common goals }\end{array}$ \\
\hline & Holistic thinking & $\begin{array}{c}\text { Able to understand the professional field, roles, and } \\
\text { duties as a part of a complex } \\
\text { multidimensional system }\end{array}$ & $\begin{array}{l}\text { Maintains a global vision to operate in a } \\
\text { complex multidisciplinary system }\end{array}$ \\
\hline & Long term vision & $\begin{array}{l}\text { Able to plan and anticipate future events and foresee } \\
\text { upcoming problems, keeping in mind the final goal }\end{array}$ & $\begin{array}{l}\text { Forms and shares a long-term vision, } \\
\text { anticipating future events with a } \\
\text { suitable approach }\end{array}$ \\
\hline & Conflict management & $\begin{array}{l}\text { Able to solve conflicts effectively, avoiding conflict } \\
\text { when possible; manages conflict properly to } \\
\text { improve group relationships; listens to and } \\
\text { communicates with others to find causes of conflict }\end{array}$ & $\begin{array}{c}\text { Identifies and manages conflicts between } \\
\text { different parts, aligning various needs and } \\
\text { points of view considering diversity and } \\
\text { multiculturality }\end{array}$ \\
\hline & Ethical orientation & $\begin{array}{l}\text { Guided in one's actions by the concept of right and } \\
\text { wrong, respects people and life in general }\end{array}$ & $\begin{array}{l}\text { Demonstrates behavior based on ethical } \\
\text { principles and integrity in the work }\end{array}$ \\
\hline \multirow{4}{*}{ 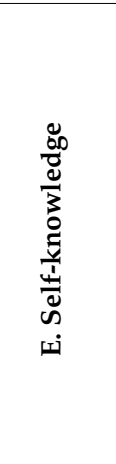 } & Self-awareness & $\begin{array}{l}\text { Conscious of one's feelings, needs, and desires; } \\
\text { sensitive to how one's communication and behavior } \\
\text { could be interpreted by others }\end{array}$ & $\begin{array}{l}\text { Aware of one's feelings, needs, strengths, } \\
\text { and weaknesses }\end{array}$ \\
\hline & Cultural knowledge & $\begin{array}{l}\text { Aware of different dimensions of cultural variation } \\
\text { and how these might influence understanding, } \\
\text { emotions, behavior, and interactions }\end{array}$ & $\begin{array}{l}\text { Demonstrates knowledge of cultural differences } \\
\text { and how these might influence understanding, } \\
\text { emotions, behavior, and interactions }\end{array}$ \\
\hline & Responsibility & Aware of the worth of one's actions and behaviors & $\begin{array}{l}\text { Responds to duties with integrity and convinced } \\
\text { that one's actions will communicate well-being } \\
\text { to the system }\end{array}$ \\
\hline & Resilience & $\begin{array}{l}\text { Able to develop coping mechanisms to resist and } \\
\text { deal with stress and uncertainty, and } \\
\text { difficult moments }\end{array}$ & $\begin{array}{l}\text { Recovers strongly from crises, difficulties, } \\
\text { and failures }\end{array}$ \\
\hline
\end{tabular}


Table 3. Cont

\begin{tabular}{|c|c|c|c|}
\hline Cluster & Competencies & Definition & $\begin{array}{l}\text { Item Performance Indicator for } \\
\text { Self-Assessment }\end{array}$ \\
\hline \multirow{7}{*}{ 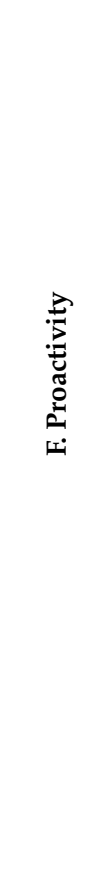 } & Curiosity & $\begin{array}{c}\text { Interested in new experiences related to new things; } \\
\text { willing to deepen below the surface; interested in } \\
\text { many different experiences }\end{array}$ & $\begin{array}{l}\text { Looks for new knowledge and opportunities for } \\
\text { continuous learning }\end{array}$ \\
\hline & Change promotion & $\begin{array}{l}\text { Able to study consumers' or employees' behaviors } \\
\text { shaped by internal conditions and external } \\
\text { influences; uses language and informative tools to } \\
\text { promote new ideas or projects }\end{array}$ & $\begin{array}{l}\text { Acts as a change agent, taking positive action to } \\
\text { capitalize on opportunities }\end{array}$ \\
\hline & Oriented to face challenges & $\begin{array}{l}\text { Guided by values and beliefs to achieve important } \\
\text { and difficult goals; possesses personal toughness } \\
\text { that enables maintaining a sense of focus in difficult } \\
\text { situations; self-disciplined and self-reliant }\end{array}$ & $\begin{array}{l}\text { Faces challenges actively to achieve important, } \\
\text { relevant. and global goals }\end{array}$ \\
\hline & Acceptance of differences & $\begin{array}{l}\text { Interested in other cultures but also open to people } \\
\text { from different backgrounds and willing to make an } \\
\text { effort to approach them }\end{array}$ & $\begin{array}{l}\text { Acknowledges and appreciates differences in } \\
\text { people, cultures and backgrounds }\end{array}$ \\
\hline & Openness & $\begin{array}{l}\text { Listens to and understands opinions and interests } \\
\text { that do not conflict with one's position and gets } \\
\text { tense when differences are expressed }\end{array}$ & $\begin{array}{l}\text { Welcomes different opinions and behaviors } \\
\text { coming from diverse and multicultural } \\
\text { environments }\end{array}$ \\
\hline & Initiative & $\begin{array}{l}\text { Uses one's experience and abilities to consciously } \\
\text { and responsibly decide to undertake action aimed at } \\
\text { specific purpose }\end{array}$ & $\begin{array}{c}\text { Proposes ideas and projects to undertake action } \\
\text { toward specific purpose }\end{array}$ \\
\hline & Creativity & $\begin{array}{l}\text { Able to perceive the world in new ways, find hidden } \\
\text { patterns, make connections between seemingly } \\
\text { unrelated phenomena and generate solutions }\end{array}$ & $\begin{array}{l}\text { Provides innovative, unexpected, and original } \\
\text { ideas to create value }\end{array}$ \\
\hline
\end{tabular}




\section{Conclusions}

Recently, increasing attention has been devoted to the development of new competencies required in a global labor market. Several projects by the European Union and the OECD have investigated global competencies [6].

The TA VIE project showed that companies understand the relevance of global competencies and young professionals should improve in those competencies. Companies argue that engineers should possess these competencies to follow market trajectories. Companies in the five national contexts underlined that universities should focus their attention on developing global competencies in order to increase the quality of engineers. This reflection is common to all of the countries. Moreover, the quality of technical skills has seen a strong improvement due to industrialization and modernization processes. The recent decades have seen strong technological change and ICT expansion; indeed, engineers are required to have a global understanding of the society in which they work, and to understand all the risks and needs related to their job. An important reason for this work is to compare global competencies in different national contexts, being aware of differences across in the educational systems. This research shows that international experience is a great opportunity for engineers to strengthen these competencies.

Regarding the first research question (what are the most important competencies for engineering students to succeed in the workplace? How do you define these skills?), comparing the results of the different countries, this research found some commonalities and differences. In the five national contexts, only five global competencies are common: flexibility, adaptability, teamwork, oriented to face challenges and cooperation. All the others were found in one or some of the national contexts. These appear to be the most relevant. It can be interpreted in the sense that even if modernization and industrialization have taken similar paths across countries, national peculiarities, such as the educational system or the capitalist regime, have prevailed to prevent complete convergence across countries.

Initially 35 competencies were proposed, but this was increased to 37 global competencies for engineering students to be tested on, with suggestions added by HR specialists in each country.

This research allows us to structure the global competencies in three macro clusters (dimensions): organizational, relational and self-knowledge competencies (see Figure 3). Six sublevels were also introduced: service to organization, cooperation, communication, leadership, self-awareness and proactivity. In each group, we identified other competencies.

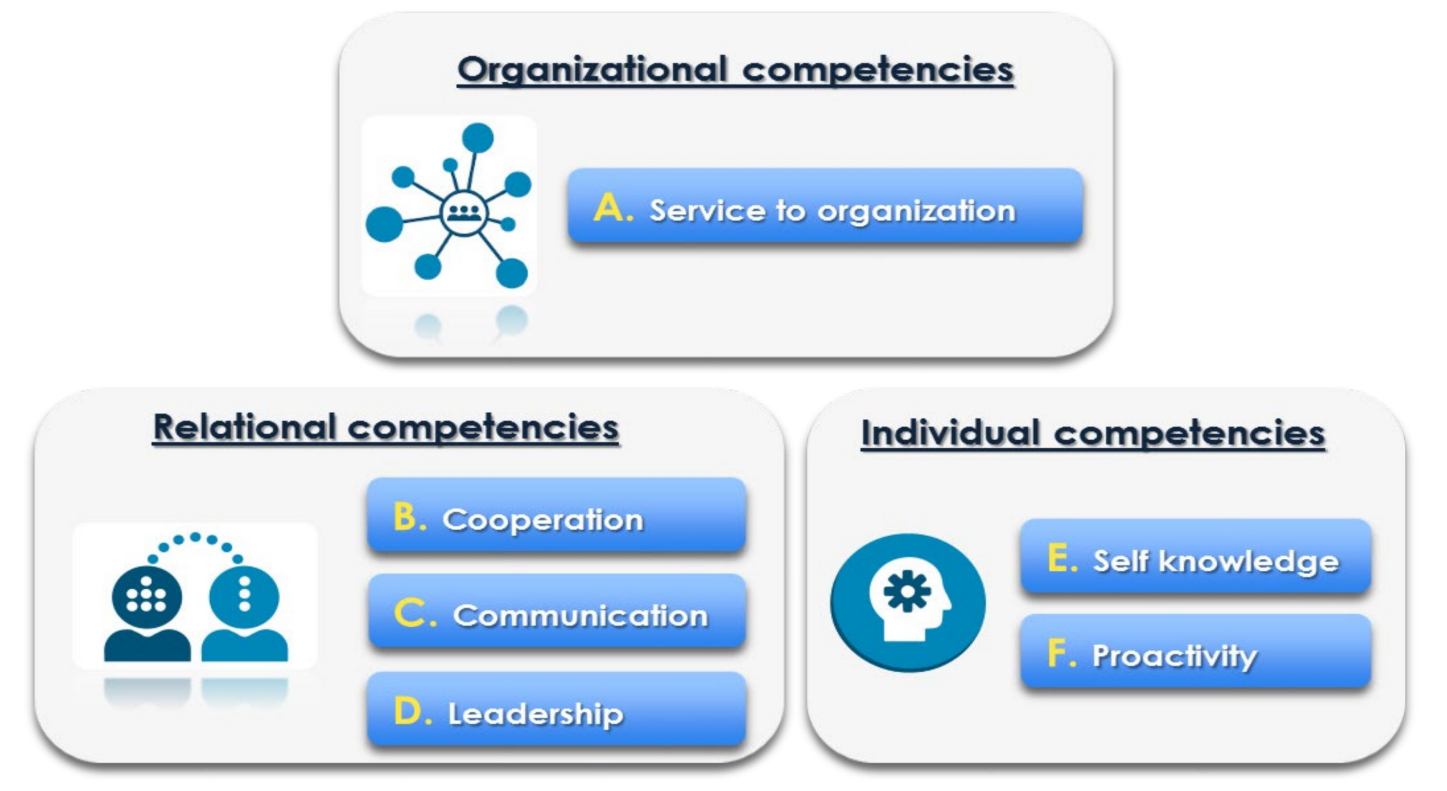

Figure 3. Tools for Enhancing and Assessing the Value of International Experience for Engineers (TA VIE) conclusion which is a framework of global competencies for engineers. 
Another interesting finding is that companies refer to international experience as a relevant quality because it often seems that young professionals with such experience show a stronger professional profile. This finding answers the second research question (does international mobility help develop these competences? How?). There is no empirical evidence showing that engineers with international mobility experience have a stronger professional profile, but most of the companies appreciate this characteristic. Indeed, several HR specialists explained that they take for granted the technical skills and focus on the global competencies during the hiring process.

From the first intellectual output of the TA VIE project, it is possible to claim that companies in general give added value to international experience because it strengthens the global competence needed today.

Regarding the third research question (Which competencies are missing in our analysis?) it is interesting to highlight another key issue which is competencies that often appear to be substantial, like flexibility and communication, are considered missing in young engineers. These skills are in strong demand but often require time and a professional career to be developed. Some of the HR specialists suggested that universities should invest more resources in supporting the development of competencies required in the labor market.

The authors recognize limitations with the work. A connection between the size and productivity features of a company and its interpretation of flexibility can be hypothesized, which could open a new line for further research. Another limitation might be related to the respondents' different interpretations of items, which could be connected to the fact that they worked in different fields that might have different role requirements for engineers. The constraint of five countries, all of them in Europe, is another limitation, and the study should be extended to other continents in order to more fully address global competence.

In addition to future steps related to these limitations, the next steps, also within the TA VIE project, will consist of measuring all competencies defined and comparing them among countries where students engage in mobility and where students do not.

As stated in the Introduction, training engineers requires an essential concern with sustainability in productivity and industrialization processes, all the more with current issues like climate change, water shortages, deforestation and pandemics. Currently, COVID-19 threatens and partly paralyzes economic and industrial activity globally. Engineering students and engineers are now travelling less. Beyond efficient communication tools, to what extent will legitimate environmental issues and COVID-19 together impact international professional mobility? Innovation is required in all fields. Global competence and its assessment are more essential and urgent than ever.

Author Contributions: Project leader, I.O.-M.; team participating in Trento, V.B., M.T. and E.V.; team participating in Nantes, F.D.; team participating in Stockholm, B.K.; team participating in Madrid, R.R.-R. and D.U.; writing—original draft preparation, V.B. and I.O.-M.; writing—review and editing, R.R.-R., F.D., B.K., D.U., M.T. and V.E. All authors have read and agreed to the published version of the manuscript.

Funding: European funding: ERASMUS+ Action 2, project number 2018-1-ES01-KA203-050477.

Acknowledgments: The authors would like to acknowledge the European Commission for funding the project which made it possible to work together on this research. We acknowledge all the companies that participated by contributing their knowledge and time.

Conflicts of Interest: The authors declare no conflict of interest.

\section{References}

1. Jesiek, B.K.; Beddoes, K. From diplomacy and development to competitiveness and globalization: Historical perspectives on the internationalization of engineering education. In What is Global Engineering Education for: The Making of International Educators; Downey, G.L., Beddoes, K., Eds.; Morgan and Claypool: San Rafael, CA, USA, 2010; pp. 45-76. 
2. Organisation for Economic Co-Operation and Development (OECD). In-Depth Analysis of the Labour Market Relevance and Outcomes of Higher Education Systems: Analytical Framework and Country Practices Report; Enhancing Higher Education System Performance; OECD: Paris, France, 2017.

3. Kioupi, V.; Voulvoulis, N. Education for Sustainable Development: A systemic Framework for Connecting the SDGs to Educational Outcomes. Sustainability 2019, 11, 6104. [CrossRef]

4. Leal Filho, W.; Pace, P. Teaching Education for Sustainable Development at University Level; Springer International Publishing: Cham, Switzerland, 2016.

5. Mochizuki, Y.; Fadeeva, Z. Competences for sustainable development and sustainability: Significance and challenges for ESD. Int. J. Sustain. High. Educ. 2010, 11, 391-403. [CrossRef]

6. Grandin, J.; Hirleman, E.D. Educating engineers as global citizens: A call for action/a report of the national summit meeting on the globalization of engineering education. Online J. Glob. Eng. Educ. 2009, 4, 1-28.

7. Katehi, L. The global engineer. In Educating the Engineer of 2020; NAE, Ed.; The National Academies Press: Washington, DC, USA, 2005; pp. 151-155.

8. Global Engineering Excellence Initiative. In Search of Global Engineering Excellence: Educating the Next Generation of Engineers for the Global Workplace; Continental AG: Hanover, Germany, 2006.

9. Huckle, J.; Wals, A.E.J. The UN Decade of Education for Sustainable Development: Business as usual in the end. Environ. Educ. Res. 2015, 21, 491-505. [CrossRef]

10. Lozano, R.; Lozano, F.J.; Mulder, K.; Huisingh, D.; Waas, T. Advancing Higher Education for Sustainable Development: International insights and critical reflections. J. Clean Prod. 2013, 48, 3-9. [CrossRef]

11. Eizaguirre, A.; Feijoo, M.G.; Laka, J.P. Defining Sustainability Core Competencies in Business and Management Studies Based on Multinational Stakeholders' Perceptions. Sustainability 2019, 11, 2303. [CrossRef]

12. Buckler, C.; Creech, H. Shaping the Future We Want: UN Decade of Education for Sustainable Development (2005-2014); Final Report; UNESCO: Paris, France, 2014; Available online: https://unesdoc.unesco.org/ark: /48223/pf0000230302 (accessed on 30 September 2020).

13. Perez Salgado, F.; Abbott, D.; Wilson, G. Dimensions of professional competences for interventions towards sustainability. Sustain. Sci. 2018, 13, 163-177. [CrossRef]

14. Kestin, T.; van den Belt, M.; Denby, L.; Ross, K.E.; Thwaites, J.; Hawkes, M. Getting Started with the SDGs in Universities: A Guide for Universities, Higher Education Institutions, and the Academic Sector. 2017. Available online: http://ap-unsdsn.org/regional-initiatives/universities-sdgs/university-sdg-guide/ (accessed on 30 September 2020).

15. Yáñez, S.; Uruburu, Á.; Moreno, A.; Lumbreras, J. The sustainability report as an essential tool for the holistic and strategic vision of higher education institutions. J. Clean. Prod. 2019, 207, 57-66. [CrossRef]

16. Lozano, R.; Barreiro-Gen, M.; Lozano, F.J.; Sammalisto, K. Teaching Sustainability in European Higher Education Institutions: Assessing the Connections between Competences and Pedagogical Approaches. Sustainability 2019, 11, 1602. [CrossRef]

17. Mulder, K.F.; Segalàs, J.; Ferrer-Balas, D. How to educate engineers for/in sustainable development: Ten years of discussion, remaining challenges. Int. J. Sustain. High. Educ. 2012, 13, 211-218. [CrossRef]

18. Barrón, Á.; Navarrete, A.; Ferrer-Balas, D. Sostenibilización curricular en las universidades españolas. ¿Ha llegado la hora de actuar? Rev. Eureka Enseñ. Divul. Cien. 2010, 7, 388-399.

19. UNESCO. Declaración Mundial Sobre la Educación Superior en el Siglo XXI. 1998. Available online: http://www.unesco.org/education/educprog/wche/declaration_spa.htm (accessed on 30 September 2020).

20. Moreso, J.J.; Casadesús, M. Preparing the Global Citizenry, Implications for the Curriculum. In Higher Education in the World 6. Towards a Socially Responsible University: Balancing the Global with the Local; Global University Network for Innovation (GUNI): Girona, Spain, 2017; pp. 181-193. Available online: http://www.guninetwork.org/files/download_full_report.pdf (accessed on 29 September 2020).

21. Tilbury, D. Higher education for sustainability: A global overview of commitment and progress. In Higher Education in the World 4. Higher Education's Commitment to Sustainability from Understanding to Action; Global University Network for Innovation (GUNI): Girona, Spain, 2011; pp. 18-28.

22. DeWit, H.; Leask, B. Reimagining the Curriculum for the 21st Century. In Higher Education in the World 6. Towards a Socially Responsible University: Balancing the Global with the Local; Global University Network for Innovation, GUNI: Girona, Spain, 2017; pp. 222-235. Available online: http://www.guninetwork.org/files/ (accessed on 29 September 2020). 
23. Cebrián, G.; Junyent, M. Competences in Education for Sustainable Development: Exploring the Student Teachers' Views. Sustainability 2015, 7, 2768. [CrossRef]

24. Deardorff, D.K. The identification and assessment of intercultural competence as a student outcome of internationalization at institutions of higher education in the United States. J. Stud. Int. Educ. 2006, 10, 241-266. [CrossRef]

25. Grigg, N.S. Broad, global, and multidisciplinary civil engineering education. J. Civ. Eng. Educ. 2014, 140, 02513002. [CrossRef]

26. Yates, J.K. Globalization of engineering and construction legal issues. J. Civ. Eng. Educ. 2007, 133, 169-170. [CrossRef]

27. Miñano Rubio, R.; Uribe, D.; Moreno-Romero, A.; Yáñez, S. Embedding Sustainability Competences into Engineering Education. The Case of Informatics Engineering and Industrial Engineering Degree Programs at Spanish Universities. Sustainability 2019, 11, 5832. [CrossRef]

28. Spitzberg, B.H.; Changnon, G. Conceptualizing intercultural competence. In The SAGE Handbook of Intercultural Competence; Deardorff, D.K., Ed.; Sage: Thousand Oaks, CA, USA, 2009; pp. 2-52.

29. Grosseck, G.; Tîru, L.G.; Bran, R.A. Education for sustainable development: Evolution and perspectives: A bibliometric review of research, 1992-2018. Sustainability 2019, 11, 6136. [CrossRef]

30. Uribe, D.F.; Ortiz-Marcos, I.; Uruburu, Á. What is going on with stakeholder theory in Project Management literature? A symbiotic relationship for sustainability. Sustainability 2018, 10, 1300. [CrossRef]

31. Sterling, S. Separate tracks or real synergy? Achieving a closer relationship between Education and SD, Post 2015. J. Educ. Sustain. Dev. 2014, 8, 89-112. [CrossRef]

32. Organisation for Economic Co-Operation and Development (OECD). Preparing Our Youth for an Inclusive and Sustainable World. The OECD PISA Global Competence Framework; OECD: Paris, France, 2018.

33. Lohmann, J.R.; Rollins, H.A., Jr.; Hoey, J.J. Defining, developing and assessing global competence in engineers. Eur. J. Eng. Educ. 2006, 31, 119-131. [CrossRef]

34. Parkinson, A. The rationale for developing global competence. Online J. Glob. Eng. Educ. 2009, 4, 2.

35. Downey, G.; Lucena, J.C.; Moskal, B.; Bigley, T.; Hays, C.; Jesiek, B.; Parkhurst, R. The globally competent engineer: Working effectively with people who define problems differently. J. Eng. Educ. 2006, 105, 107-122. [CrossRef]

36. Bell, D. The Coming of Post-Industrial Society; Basic Books: New York, NY, USA, 1973.

37. Blau, P.; Duncan, O.D. The American Occupational Structure; Wiley: New York, NY, USA, 1967.

38. Inglehart, R.; Welzel, C. Modernization. In The Blackwell Encyclopedia of Sociology; John Wiley \& Sons: Hoboken, NJ, USA, 2007. [CrossRef]

39. Busemeyer, M.R.; Vossiek, J. Global Convergence or Path Dependency? Skill Formation Regimes in the Globalized Economy. In The Handbook of Global Education Policy; John Wiley \& Sons, Ltd.: Hoboken, NJ, USA, 2016; pp. 145-161. [CrossRef]

40. Baccaro, L.; Pontusson, J. Rethinking comparative political economy: The Growth Model. Politics Soc. 2016, 44, 175-207. [CrossRef]

41. Breen, R.; Jonsson, J.O. Inequality of Opportunity in Comparative Perspective: Recent Research on Educational Attainment and Social Mobility. Annu. Rev. Sociol. 2005, 31, 223-243. [CrossRef]

42. Bratti, M.; Checchi, D.; de Blasio, G. Does the expansion of higher education increase the equality of educational opportunities? Evidence from Italy. Labour 2008, 22, 53-88. [CrossRef]

43. Bernardi, F.; Ballarino, G. Participation, equality of opportunity and returns to tertiary education in contemporary Europe. Eur. Soc. 2014, 16, 422-442. [CrossRef]

44. Bol, T. Has education become more positional? Educational expansion and labor market outcomes, $1985-2007$. Acta Sociol. 2015, 58, 105-120. [CrossRef]

45. Klein-Gardner, S. Defining Global Competence for Engineering Students; American Society for Engineering Education: Washington, DC, USA, 2011.

46. Goldin, C.; Katz, L. The Race between Education and Technology: The Evolution of U.S. Educational Wage Differentials, 1890 to 2005; Working Paper, No. 12984; National Bureau of Economic Research: Cambridge, MA, USA, 2007.

47. Crouch, C.; Finegold, D.; Sako, M. Are Skills the Answer? The Political Economy of Skill Creation in Advanced Industrial Countries; Oxford Press: Oxford, UK, 1999. 
48. Hall, P.; Soskice, D. Varieties of Capitalism: The Institutional Foundations of Comparative Advantage; Oxford University Press: Oxford, UK, 2001.

49. Hancké, B.; Rhodes, M.; Thatcher, M. Beyond Varieties of Capitalism: Conflict, Contradictions, and Complementarities in the European Economy; Oxford Scholarship: Oxford, UK, 2007.

50. Handford, M.; Maele, J.V.; Matous, P.; Maemura, Y. Which "culture"? A critical analysis of intercultural communication in engineering education. J. Eng. Educ. 2019, 108, 161-177. [CrossRef]

51. ABET. Criteria for Accrediting Engineering Programs. Effective for Reviews during the 2015-2016 Accreditation Cycle; ABET: Baltimore, MD, USA, 2014.

52. ENAEE. EUR-ACE Framework Standards and Guidelines. Available online: https://www.enaee.eu/wpassets-enaee/uploads/2015/04/EUR-ACE-Framework-Standards-and-Guidelines-Mar-2015.pdf (accessed on 20 September 2020).

53. ABET. Criteria for Accrediting Engineering Programs. Effective for Reviews during the 2019-2020 Accreditation Cycle; ABET: Baltimore, MD, USA, 2018.

54. Johri, A.; Jesiek, B.K. Global and international issues in engineering education. In Cambridge Handbook of Engineering Education Research; Johri, A., Olds, B.M., Eds.; Cambridge University Press: New York, NY, USA, 2014; pp. 655-672.

55. Parkinson, A. Engineering study abroad programs: Formats, challenges, best practices. Online J. Glob. Eng. Educ. 2007, 2, 1-15.

56. Arasaratnam, L.A. Ten years of research in intercultural communication competence: A retrospective. J. Intercul. Commun. 2014, 35, 1-12.

57. Mazzurco, A.; Jesiek, B.K.; Godwin, A. Development of Global Engineering Competency Scale: Exploratory and Confirmatory Factor Analysis. J. Civ. Eng. Educ. 2020, 146, 04019003. [CrossRef]

58. Fantini, A.E. Assessing intercultural competence: Issues and tools. In The SAGE Handbook of Intercultural Competence; Deardorff, D.K., Ed.; Sage: Thousand Oaks, CA, USA, 2009; pp. 456-476.

59. European Council. European Council Meeting (14 December 2017) Conclusions about the European Universities Initiative. Available online: https://www.consilium.europa.eu/media/32204/14-final-conclusionsrev1-en.pdf (accessed on 29 September 2020).

60. King, P.M.; Baxter Magolda, M.B. A Developmental Model of Intercultural Maturity. J. Coll. Stud. Dev. 2005, 46, 571-592. [CrossRef]

61. Wiek, A.; Withycombe, L.; Redman, C.L. Key competencies in sustainability: A reference framework for academic program development. Sustain. Sci. 2011, 6, 203-218. [CrossRef]

62. Ayers, J. Competence Literate but Context Lacking? Investigating the Potential of Study Abroad Programs to Promote Sustainability Competence Acquisition in Students. Sustainability 2020, 12, 5389. [CrossRef]

63. Jesiek, B.K.; Eun Woo, S.; Parrigon, S.; Porter, C.M. Development of a situational judgment test for global engineering competence. J. Eng. Educ. 2020, 109, 470-490. [CrossRef]

64. Davies, R.; Zaugg, H.; Tateishi, I. Design and development of a cross-cultural disposition inventory. Eur. J. Eng. Educ. 2015, 40, 81-94. [CrossRef]

65. Mazzurco, A.; Jesiek, B.K.; Ramane, K. Are engineering students culturally intelligent? Preliminary results from a multiple group study. In Proceedings of the ASEE Annual Conference and Exposition, San Antonio, TX, USA, 10-13 June 2012.

66. Bielefeldt, A.; Paterson, K.; Swan, C. Measuring the value added from service learning in project-based engineering education. Int. J. Eng. Educ. 2010, 26, 535-546.

67. Groll, L. Negotiating Cultural Humility: First-Year Engineering Students' Development in a Life-Long Journey (Unpublished Doctoral Dissertation); Purdue University: West Lafayette, IN, USA, 2013.

68. Jesiek, B.K.; Shen, Y.; Haller, Y. Cross-cultural competence: A comparative assessment of engineering students. Int. J. Eng. Educ. 2012, 28, 144-155.

69. Atman, C.J.; Adams, R.S.; Cardella, M.E.; Turns, J.; Mosborg, S.; Saleem, J. Engineering design processes: A comparison of students and expert practitioners. J. Eng. Educ. 2007, 96, 359-379. [CrossRef]

70. Kilgore, D.; Atman, C.J.; Yasuhara, K.; Barker, T.J.; Morozov, A. Considering context: A study of first-year engineering students. J. Eng. Educ. 2007, 96, 321-334. [CrossRef] 
71. Deardorff, D.K. The SAGE Handbook of Intercultural Competence; Sage: Thousand Oak, CA, USA, 2009.

Publisher's Note: MDPI stays neutral with regard to jurisdictional claims in published maps and institutional affiliations.

(C) 2020 by the authors. Licensee MDPI, Basel, Switzerland. This article is an open access article distributed under the terms and conditions of the Creative Commons Attribution (CC BY) license (http://creativecommons.org/licenses/by/4.0/). 